\title{
Controversies in management of multiple pregnancy
}

\author{
Tiran Dias ${ }^{1}$
}

\section{Introduction}

Twin pregnancies are at increased risk of complications than singletons ${ }^{1,2}$. These complications can develop throughout gestation and pose greater risk to both mother and babies. Early pregnancy scanning enables accurate pregnancy dating, determination of chorionicity, labelling and possible risk prediction in monochorionic twin pregnancies ${ }^{3-7}$. This article focuses mainly on controversies in screening and prevention of preterm labour (PTL), fetal growth restriction (FGR) and preeclampsia in multiple pregnancy.

\section{Preterm labour}

Twin pregnancies are more likely to be delivered preterm than singleton pregnancies $^{8}$. More than $50 \%$ of twins and almost all triplets are born before 37 weeks of gestation and about 15-20\% of admissions to neonatal units are associated with preterm twins and triplets. In 2006, of the 137,085 twins delivered in the United States, approximately $60 \%$ were preterm and weighed $<2500 \mathrm{~g}^{8}$. Preterm birth can be following preterm pre labour rupture of membranes (pPROM), medically indicated/ iatrogenic preterm birth and birth following spontaneous onset of preterm labour without $\mathrm{pPROM}^{9}$. Schaaf et al. revealed that the commonest aetiology for preterm birth in twins was due to spontaneous onset preterm labour without $\mathrm{pPROM}^{10}$. Cervical length, cervico-vaginal fibronectin test, additional antenatal care, obstetric history and composite measures are recognised methods of

${ }^{1}$ Consultant Obstetrician and Gynaecologist District General Hospital, Ampara.

Correspondence: Tiran Dias

E-mail: thiran_dias@yahoo.com

Competing interests: None screening in preterm births in singletons. It has become apparent that in singleton pregnancies, cervical length screening between 19 and 24 weeks and progesterone prophylaxis in women with a short cervix would reduce the incidence of preterm birth before 33 weeks by $45 \%{ }^{11}$.

There is evidence that a short cervical length, especially less than 15 $\mathrm{mm}$, at 22-24 weeks of gestation in twin pregnancies is a good predictor of preterm birth up to 32 weeks of gestation. However, a short cervix was not predictive of birth before 37 weeks. To et al. carried out a study of cervical length measurement in twins between 22 and 24 weeks' gestation and reported that the risk of delivery before 32 weeks' gestation was strongly associated with cervical length. Using cut-offs of $<25 \mathrm{~mm},<20 \mathrm{~mm}$ and $<15$ $\mathrm{mm}$, the respective detection rates of spontaneous preterm birth before 32 weeks' gestation were $35 \%, 49 \%$ and $67 \%$ respectively ${ }^{12}$. There is also evidence that a cervical length less than $25 \mathrm{~mm}$ measured at 14-20 weeks in triplet pregnancies is associated with spontaneous preterm birth before 32 weeks $^{13}$. In contrast, prediction of preterm labour with positive fetal fibronectin test result is poor in twin pregnancies $^{14,15}$. However, if fetal fibronectin is used in conjunction with cervical length, the ability of the test to identify women who are at a significantly higher risk of preterm birth was improved ${ }^{16}$. Home uterine activity monitoring in twin pregnancies is not useful in predicting spontaneous preterm birth ${ }^{17,18}$. Previous history of preterm birth with a singleton pregnancy is also a significant risk factor of preterm birth in twin pregnancies ${ }^{19}$.

Since preterm birth is associated with considerable morbidity and mortality it is relevant to identify treatments which could prevent spontaneous preterm birth in twin preg- nancy. Treatment options such as bed rest, progesterone, cervical cerclage and tocolytics have been proposed in singletons as preventive strategies in preterm labour. Current evidence suggests that bed rest does not reduce the incidence of spontaneous preterm birth before 37 weeks of gestation, gestational age at birth or perinatal mortality in twins and triplets ${ }^{20-21}$. Furthermore, there is no evidence that progesterone (intramuscular or vaginal) prevents spontaneous preterm births in twins and triplets ${ }^{22-25}$. Oral betamimetics or cervical cerclage in twins and triplets do not prevent preterm labour ${ }^{26-28}$. Paradoxically, cervical cerclage in those with a short cervix (less than $25 \mathrm{~mm}$ ) increases the risk of early preterm birth ${ }^{29}$. Considering above facts, routine screening for preterm labour in twins and triplets is not recommended.

\section{Fetal growth restriction}

Under normal circumstances, twins grow at the same rate as singletons up to at least 32 weeks' gestation, regardless of chorionicity ${ }^{30-31}$. After 32 weeks' gestation, studies described slower rates of growth for twins ${ }^{31}$. The decreased rate may be related to reduce intrauterine physical space or uteroplacental insufficiency. The assessment of fetal growth is an essential component of good antenatal care $^{32}$. Symphisio-fundal distance (SFD) measurement is inappropriate for growth monitoring in multiple pregnancies. Ultrasound biometry is now standard for growth assessment in multiple pregnancies. Similar to singleton pregnancies, the aetiology for fetal growth restriction (FGR) in DC twins can be diverse and includes uteroplacental insufficiency, infection, genetic/chromosomal problems, fetal anatomical anomalies, placental and cord abnormalities, maternal complications such as chronic hypertension and pregnancy-induced hypertension. 
Although FGR can coexist with growth discordance, the latter does not necessarily imply the former. Growth discordance can be a marker for FGR. It is important to note that FGR can also affect both twins, leading to both twins being small but not discordant.

Growth discordance is a unique complication of twin gestations and can be defined in three ways. First, the 'absolute definition' only considers the birthweight difference between the smaller and the larger twin. This definition assigns the same degree of discordance to a twin pair of 3000/ $2500 \mathrm{~g}$ and another pair of 1500/1000 $\mathrm{g}^{33}$. The second definition is the "per cent definition', in which birthweight disparity is calculated as a percentage of the larger infant ${ }^{33}$. The third definition is 'statistically derived' in which birthweight differences are expressed either in terms of 95th percentile or in standard deviations from a predefined mean of twin birthweights. However, populationbased data in a large series of twin births has revealed that birthweight discordance does not have a normal (Gaussian) distribution and thus central measures like the mean and standard deviation do not describe the situation appropriately ${ }^{33}$. Fetal growth in DC twins is normally assessed every four weeks by ultrasound biometry. In case of severe growth discordance with extreme prematurity, delivery can be delayed till viability to give the maximum benefit to the healthy twin. The healthy twin should not be compromised in the event of a co-twin death, as they have two different placental vascular systems. In a large study including more than 2,000 twin pregnancies, D'Antonio et al demonstrated that perinatal loss in twins with a birth weight discordance of more than $25 \%$ was significantly greater (60.9 per 1,000 fetuses) compared to those with a discordance less than $25 \%$ (8.6 per 1,000 fetuses $)^{34}$. Their analysis further demonstrated that birth weight discordance and gestational age, but not chorionicity and individual fetal size percentile, were the only independent predictors of perinatal mortality in twin pregnancies $^{34}$.

It is now recommended not to use abdominal palpation or symphysisfundal height measurements to predict intrauterine growth restriction in twin or triplet pregnancies and ultrasound fetal biometry should be used four weekly to assess fetal growth and it should be plotted from 28 weeks. Furthermore, it is appropriate to estimate fetal weight discordance using two or more biometric parameters at each ultrasound scan from 20 weeks. Estimated fetal weight discordance $>25 \%$ should be considered significant in twins or triplets as it is a clinically important indicator of intrauterine growth restriction and offer referral to a tertiary level fetal medicine centre. Routine measurement of umbilical artery Doppler ultrasound alone to monitor intrauterine growth restriction or birthweight in twin or triplet pregnancies is not recommended.

\section{Preeclampsia}

Preeclampsia is a significant cause of maternal morbidity and mortality. Twin and triplet pregnancies are associated with an increased risk of pregnancy induced hypertension and women with twin pregnancies have a threefold higher risk of developing hypertension during pregnancy than women with singleton pregnancies ${ }^{35-38}$. Combination of maternal characteristics, uterine artery Doppler studies and maternal serum biochemistry has been used to screen preeclampsia in singleton pregnancies. Screening for hypertension in twin and triplet pregnancies is not convincing as in singletons. Uterine artery Doppler (particularly pulsatility index more than the 95th centile) in twins shows high negative predictive value and this could be used to exclude the risk. Since it is not sensitive enough to predict preeclampsia, its routine use is not recommended. Multiple pregnancy carries a moderate risk of preeclampsia. Therefore, it is recommended to start low dose aspirin to all twins and triplets who have any of the other moderate risk factors for preeclampsia (first pregnancy, age 40 years or older, pregnancy interval of more than 10 years, BMI of $35 \mathrm{~kg} / \mathrm{m}^{2}$ or more at first visit, or family history of preeclampsia) $)^{39}$.

\section{REFERENCES}

1. Dias T, Bhide A, Thilaganathan B. Early pregnancy growth and pregnancy outcome in twin pregnancies. Ceylon Medical Journal. 2010; 55(3): 80-4.

2. Dias $T$, Contro $E$, Thilaganathan $B$, Khan $\mathrm{H}$, Zanardini C, Mahsud-Dornan S, Bhide A. Pregnancy outcome of monochorionic twins: does amnionicity matter? Twin Res Hum Genet. 2011; 14(6): 586-92.

3. Dias T, Arcangeli T, Bhide A, et al. Firsttrimester ultrasound determination of chorionicity in twin pregnancy. Ultrasound in Obstetrics and Gynecology. 2011; 38(5): 530-2.

4. Dias T, Mahsud-Dornan S, Thilaganathan $B$, et al. First-trimester ultrasound dating of twin pregnancy: are singleton charts reliable? British Journal of Obstetrics and Gynaecology. 2010; 117(8): 979-84.

5. Dias T, Ladd S, Mahsud-Dornan S, Bhide A, Papageorghiou AT, Thilaganathan B. Systematic labeling of twin pregnancies on ultrasound. Ultrasound Obstet Gynecol 2011; 38(2): 130-3.

6. Dias T. Screening for chromosomal defects. Sri Lanka Journal of Obstetrics and Gynaecology 33 (3): 124-28.

7. Memmo A, Dias T, Mahsud-Dornan S, et al. Prediction of selective fetal growth restriction and twin-to-twin transfusion syndrome in monochorionic twins. British Journal of Obstetrics and Gynaecology. 2012; 119(4): 417-21.

8. Martins WP, Nastri CO, Barra DA, Navarro PA, Mauad Filho F, Ferriani RA. Fetal volume and crown-rump length from 7 to 10 weeks of gestational age in singletons and twins. Eur J Obstet Gynecol Reprod Biol 2009; 145(1): 32-5.

9. Ananth CV, Joseph KS, Demissie K, Vintzileos AM. Trends in preterm birth and perinatal mortality among singletons: United States, 1989 through 2000. 2005; Obstet Gynecol 105: 1084-91. 
10. Schaaf J, Mol B, Abu-Hanna A, Ravelli A. Trends in preterm birth: singleton and multiple pregnancies in the Netherlands, 2000-2007. BJOG 2011; 118(10): 1196-204.

11. Hassan SS, Romero R, Vidyadhari $D$, Fusey S, Baxter JK, Khandelwal M, Vijayaraghavan J, Trivedi Y, Soma-Pillay $P$, Sambarey P, Dayal A, Potapov V, O'Brien J, Astakhov V, Yuzko O, Kinzler W, Dattel B, Sehdev H, Mazheika L, Manchulenko D, Gervasi MT, Sullivan L, Conde-Agudelo A, Phillips JA, Creasy GW; PREGNANT Trial. Vaginal progesterone reduces the rate of preterm birth in women with a sonographic short cervix: a multicenter, randomized, double-blind, placebo-controlled trial. Ultrasound Obstet Gynecol 2011; 38(1): 18-31.

12. To MS, Fonseca EB, Molina FS, Cacho AM, Nicolaides KH. Maternal characteristics and cervical length in the prediction of early spontaneous preterm delivery in twins. Am J Obstet Gynecol 2006; 194: 1360-65.

13. Guzman ER, Walters C. O'Reilly-Green $C$ et al. Use of cervical ultrasonography in prediction of spontaneous preterm birth in triplet gestations. American Journal of Obstetrics and Gynecology 2000; 183:(5) 1108-13.

14. Gibson JL, Macara LM, Owen $P$, et al. Prediction of preterm delivery in twin pregnancy: a prospective, observational study of cervical length and fetal fibronectin testing. Ultrasound in Obstetrics and Gynecology 2004; 23: 561-6.

15. Wennerholm UB, Holm B, MattsbyBaltzer I, et al. Fetal fibronectin, endotoxin, bacterial vaginosis and cervical length as predictors of preterm birth and neonatal morbidity in twin pregnancies. British Journal of Obstetrics and Gynaecology 1997; 104:(12) 1398-404

16. Fox NS, Saltzman DH, Klauser CK, et al. Prediction of spontaneous preterm birth in asymptomatic twin pregnancies with the use of combined fetal fibronectin and cervical length. American Journal of Obstetrics and Gynecology 2009; 201:(3) 313-5.

17. Colton $\mathrm{T}$, Kayne HL, Zhang $\mathrm{Y}$, et al. A metaanalysis of home uterine activity monitoring. American Journal of Obstetrics and Gynecology 1995; 173:(5) 1499-505.

18. Dyson DC, Danbe KH, Bamber JA. Monitoring women at risk of preterm labor. New England Journal of Medicine 1998; 338: 15-9.
19. Facco FL, Nash K, Grobman WA. Are women who have had a preterm singleton delivery at increased risk of preterm birth in a subsequent twin pregnancy? American Journal of Perinatology 2008; 25: (10) 657-9.

20. Crowther CA. Hospitalisation and bed rest for multiple pregnancy. Cochrane Database of Systematic Reviews 2009;(4).

21. Kappel B, Hansen KB, Moller J, et al. Bed rest in twin pregnancy. Acta Geneticae Medicae et Gemellologiae 1985; 34:(1-2) 67-71.

22. Norman JE, Mackenzie $F$, Owen $P$, Mactier H, Hanretty K, Cooper S, Calder A, Mires G, Danielian P, Sturgiss S, MacLennan G, Tydeman G, Thornton S, Martin B, Thornton JG, Neilson JP, Norrie J. Progesterone for the prevention of preterm birth in twin pregnancy (STOPPIT): a randomised, double blind, placebo-controlled study and metaanalysis. Lancet 2009; 373: 2034-40.

23. Hartikainen-Sorri AL, Kauppila A, Tuimala R. Inefficacy of 17 alpha-hydroxyprogesterone caproate in the prevention of prematurity in twin pregnancy. Obstetrics and Gynecology 1980; 56:(6) 692-5.

24. Briery CM, Morrison JC, Veillon EW, et al. Progesterone does not prevent preterm births in women with twins. Southern Medical Journal 2009; 102: (9) 900-4.

25. Rouse DJ, Caritis SN, Peaceman AM, Sciscione A, Thom EA, Spong CY, Varner M, Malone F, lams JD, Mercer BM, Thorp J, Sorokin Y, Carpenter M, Lo J, Ramin S, Harper M, Anderson G. National Institute of Child Health and Human Development MaternalFetal Medicine Units Network. A trial of 17 alpha-hydroxyprogesterone caproate to prevent prematurity in twins. $\mathrm{N}$ Engl J Med 2007; 357: 454-61.

26. Gummerus M, Halonen O. Pro-phylactic long-term oral tocolysis of multiple pregnancies. British Journal of Obstetrics and Gynaecology 1987; 94:(3) 249-51.

27. Newman RB, Krombach RS, Myers MC, et al. Effect of cerclage on obstetrical outcome in twin gestations with a shortened cervical length. American Journal of Obstetrics and Gynecology 2002; 186:(4) 634-40.

28. Elimian A, Figueroa R, Nigam $S$, et al. Perinatal outcome of triplet gestation: Does prophylactic cerclage make a difference.
Journal of Maternal-Fetal Medicine 1999; 8:(3) 119.

29. Lim AC, Hegeman MA, Huis In 'T Veld MA, Opmeer BC, Bruinse HW, Mol BW. Cervical length measurement for the prediction of preterm birth in multiple pregnancies: a systematic review and bivariate meta-analysis. Ultrasound Obstet Gynecol 2011; 38(1): 10-7.

30. Senoo M, Okamura K, Murotsuki J, Yaegashi N, Uehara S, Yajima A. Growth pattern of twins of different chorionicity evaluated by sonographic biometry. Obstet Gynecol 2000; 95: 656-61.

31. Kingdom CP, Nevi O, Murphy KE. Discordant growth in twins. Prenat Diag 2005; 25: 759-65.

32. Gardosi J. Fetal growth: towards an international standard. Ultrasound Obstet Gynecol 2005; 26(2): 112-4.

33. Blickstein I, Lancet M. The growth discordant twin. Obstet Gynecol Surv 1988; 43(9): 509-15.

34. D'Antonio F, Khalil A, Dias T, Thilaganathan B. Southwest Thames Obstetric Research Collaborative (STORK). Weight discordance and perinatal mortality in twins: analysis of the Southwest Thames Obstetric Research Collaborative (STORK) multiple pregnancy cohort. Ultrasound Obstet Gynecol 2013; 41(6): 643-8.

35. Kovacs BW, Kirschbaum TH, Paul RH. Twin gestations: I. Antenatal care and complications. Obstetrics and Gynecology 1989; 74:(3 Pt 1) 313-7.

36. Coonrod DV, Hickok DE, Zhu K, et al. Risk factors for preeclampsia in twin pregnancies: a population-based cohort study. Obstetrics and Gynecology 1995; 85:(5 Pt 1) 645-50.

37. Spellacy WN, Handler A, Ferre CD. A case-control study of 1253 twin pregnancies from a 1982-1987 perinatal data base. Obstetrics and Gynecology 1990; 75:(2) 168-71.

38. Campbell DM, MacGillivray I. Preeclampsia in twin pregnancies: incidence and outcome. Hypertension in Pregnancy 1999; 18:(3) 197-207

39. National Institute for Health and Clinical Excellence. [Multiple pregnancy: The management of twin and triplet pregnancies in the antenatal period]. [CG129]. National Institute for Health and Clinical Excellence, London, UK, 2011. 